\title{
An Analysis of Tourism Visit Trend
}

\author{
Farid Said \\ Lombok Tourism Polytechnic \\ Mataram, Indonesia \\ Rudi Salam \\ Universitas Negeri Makassar \\ Makassar, Indonesia
}

\author{
Haedar Akib \\ Universitas Negeri Makassar \\ Makassar, Indonesia
}

Aris Baharuddin

Politeknik Informatika Nasional Makassar

Makassar, Indonesia

\begin{abstract}
This research aims at analyzing tourist visits in Makassar City. The research employed a combination of quantitative and qualitative method. Moreover, the data were collected using questionnaire technique throughout the data collection form and questionnaire sheets or agreements as the sources of data and information about tourism aspects, specifically in the arrivals of domestic tourists and foreign tourists in Makassar City. Documentation technique was also used to collect secondary data from credible sources. The research was conducted by investigating documents in The Office of Culture and Tourism of Makassar City where the data had showed some increases in the last few years. The research intended to find out the use of available tourism objects and the searching or the making of new potential tourism objects, natural, socio-cultural, or human-made creation so that the numbers of visiting tourists to Makassar City were increasing.
\end{abstract}

\section{Keywords- Tourism, Visit Trend}

\section{INTRODUCTION}

The mapping of world's tourist number reported by United Nation of World Tourism Organization (UNWTO) indicated that the growth was not significant, but Asia grew bigger than any other regions. From the total portion of international visitor numbers in 1980ish, Asian Pacific only obtained 8 per-cent. Significantly, 20 years later or in 2010, Asian Pacific obtained 22 percent. Based on the data above, the expected number of tourists will increase significantly in the next 20 years, or in 2030, international visitors will flock around Asian Pacific until it reaches 30 percent [1].

The development of world tourism in Southeast Asian countries such as Malaysia, Japan, Vietnam, Cambodia, Thailand and The Philippines relies on their natures and cultures, similar to Indonesia's main tourism product, added by supported aspects. However, the phenomenon about the decrease in tourism performance in Indonesia seems to be abandoned in research works (read: Media Indonesia).

At the same time, other countries take a big portion of the world's tourism quota, which means that it also influences the tourism performance. Thus, the researchers who are focused on the study are [2]-[6]. In 2009, when the world's economy development underwent a big downturn, on the other side, Gross Domestic Product of creative industries and tourisms in Indonesia demonstrated a rising positive trend. Indonesia's tourism performance grew in 2009 because of a bigger number of tourists who went to visit. In the same year, the creative industry also grew and exhibited a positive trend for 1.5 percent. Along with the positive trend of the creative industry, in 2010, Indonesia's export also grew into 12.5 percent (Tourism and Creative, 2012). Other countries also view foreign visitors as an important asset therefore they designed intervention for international visitors like students [7].

According to the Ministry of Tourism and Creative Economy of the Republic of Indonesia, in 2011, tourist visits were 7,649,731 and the number increased in 2012 into 8 million foreign visitors. Meanwhile, the target in 2013 was expected to be able to reach 9.7 million of international visitors.

It went along realistically based on the assumptions on Indonesia's economy growth. From the aforementioned data, it can be agreed that the development of tourism sectors is closely related to the development of economy sectors. It can even be concluded that tourism sector is the leading sector of economy development. This comprehension is in line with the viewpoint of the Minister of Tourism and Creative Economy, Mari Elka Pangestu who stated that along with the rise in incomes, the number of middle classes, the improvement in infrastructures and the number of cheap flights, domestic destinations can be the national tourism main assets.

In the context of national economy development, it is clearly seen that the role of tourism sector can determine the pattern of economy activities that take place in the surrounding areas. These economy activities should become the focused attention from corresponding competent parties as the stakeholders in the development of domestic tourism sectors. Therefore, Mari Elka Pangestu as the Minister of Tourism and Creative Economy declared that domestic tourists might not be marginalized even though they did not bring dollar foreign exchange.

The statement was underlined due to the reason that domestic tourists are also needed by tourism objects in the country. The domestic tourists should be developed with the purpose to encourage the patriotism, as well as to spread the even distribution of income in Indonesia from the regions that possess high capital incomes to the regions that have lower capital incomes. The development of the tourism sectors can be seen from several indicators, and one of the indicators is the number of tourist visits as stated previously. Data source from Statistic Indonesia reported that the number of domestic visitors in star hotels and non-star hotels in 2011 was $60,347,947$.

\section{METHOD}

This research was an applied research work with the purpose of obtaining data and information (valid), incisive, and reliable about the analysis of growth and development of 

number of tourists and tourism policy in Makassar City as one of potential tourism object in Indonesia. The type of the research was quantitative and qualitative research with survey approach. Meanwhile, the data collection technique was in the form of a data collection format and questionnaire or statement sheets as the foundation to obtain data and information about various tourism aspects, especially in regards to domestic tourists and foreign tourists who come to Makassar City. The questionnaire construction followed the guideline of scale construction [6].

In addition to the questionnaire technique, a structured interview was also held to obtain data and information to figure out the tendency phenomena of Makassar City as a tourism destination in Indonesia with all of the tourism attractions and appealing activities that had been organized by the tourism stakeholders. The interview technique also provided a number of essential conceptions such as the prospect of infrastructure supplies (airports, ports) tourism objects, attractions and other supporting tourism development sectors in Makassar City.

Documentation technique used was by collecting secondary data from other trusted sources. It was carried out by investigating the documents possessed by The Office of Culture and Tourism of Makassar City as a research object. Some of the required documents were about the policy of tourism, attractive events for tourists, the persons in charge of tourism, the data of tourism development, and others. Other supporting documents were the documentation of facilities and a series of attractive events for tourists who visited Makassar City.

\section{III.RESULTS}

When tourists visit Makassar City, they must have some particular reasons in minds for choosing the tourism objects, such as specific characteristics that Makassar City has compared to other regions in Indonesia. For example, in Tanah Daeng, to attract foreign visitors as well as domestic ones, the development history of Makassar City would not be enough, there are other considerations to draw the tourists to visit the place.

Meanwhile, several other tourism attractions are Losari beach, as well as another beautiful beach, famous traditional food such as Pisang Epe', Coto Makassar and other culinary types. Those attractions can draw the tourists to visit Makassar City. It is not very clear to see if the main motives of the visits are pure for vacation or also for works. The important thing is that Makassar City has become a tourist magnet for foreign tourists as well as for domestic ones. A clearer picture of the visitors in Makassar City can be seen in Picture 1.

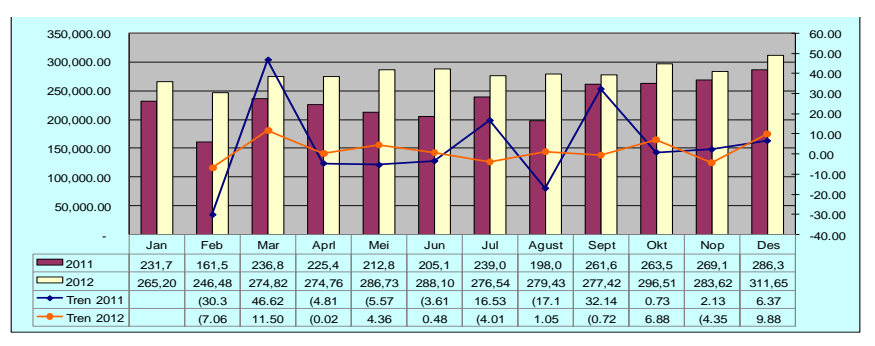

Figure 1. The Trend of Visitor Arrivals in Makassar through Sultan Hasanuddin Airport in The Year 2011-2012

Picture 1 demonstrates that the lowest number of domestic tourists who arrived in Makassar through Sultan Hasanuddin Airport was in February 2012, which was
246,484 of domestic visitors. Compared to the previous year in the same month, there were 161,531 visitors. It means the difference was 84,953 more visitors in 2012 . It was mainly caused by the intensity of domestic tourists from outside South Sulawesi who was interested in doing business or traveling in Makassar City. The next important thing is the picture clearly displays the highest number in the first semester of 2012 was in June, which was 288,103 visitors. Compared to the same month in 2011, there were 205,191 visitors where the difference was 82,912 more domestic visitors in 2012. School holidays could lead to the increasing number with the assumption that Makassar was a great place to spend holidays. In the second semester of 2012, the lowest was in July where there were 276,540 people.

Compared to the same month in 2011, there were 239,099 people where the difference was 37,441 more tourists in 2012. The highest number in 2012 was in December which was 311,653 . Compared to the same month in 2011, there were 286,311 visitors where the difference was 25,342 more domestic visitors in 2012. It must have been influenced by the fact that there were some end-year holidays; which were Christmas Holiday and New Year's Eve.

Domestic tourists are still the priority visitors in Makassar City. The above data displayed the two com-pared items in January 2011 as many as 231,769 visi-tors. Meanwhile, in January 2012, there were 265,206 people. It means, the difference between 2011 and 2012 was 33,437 more visitors in 2012. In June 2011, there were 205,191 visitors. Compared to the same month in 2012, there was a significant raise where 288,103 visitors came to Makassar City. Thus, the difference was 82,912 more visitors in 2012. This particular month was noted as having the highest difference compared to other months in these two years. Meanwhile, in December 2011 there were 286,311 visitors. Compared to the one in 2012 , there were 311,653 visitors or the difference was 25,342 more visitors in 2012.

Noticing the data analysis above showed that there was a significant increase from month to month in 2011 and 2012 where the total difference was 569,848 more domestic tourists in 2012. This could happen because the government of Makassar aggres-sively promoted the city both in the country and abroad in 2011. The City also conducted more than 100 events all along the year in 2011. It yielded in the raise of the tourist visits to Makassar City in 2012. To gain another increase in visits for the next years, promotions and events that had been conduct-ed in 2011 should be intensified in the future.

The tourists who visited Makassar City were dominantly domestic people. The data above showed that the passengers of the airplanes through Sultan Hasanuddin Airport were also the resident of Makassar City. The secondary data came from the passenger data of various flights that arrived at Sultan Hasanuddin Airport, Makassar. The data source was from Angkasa Pura I Makassar that later rear-ranged by the researchers. 


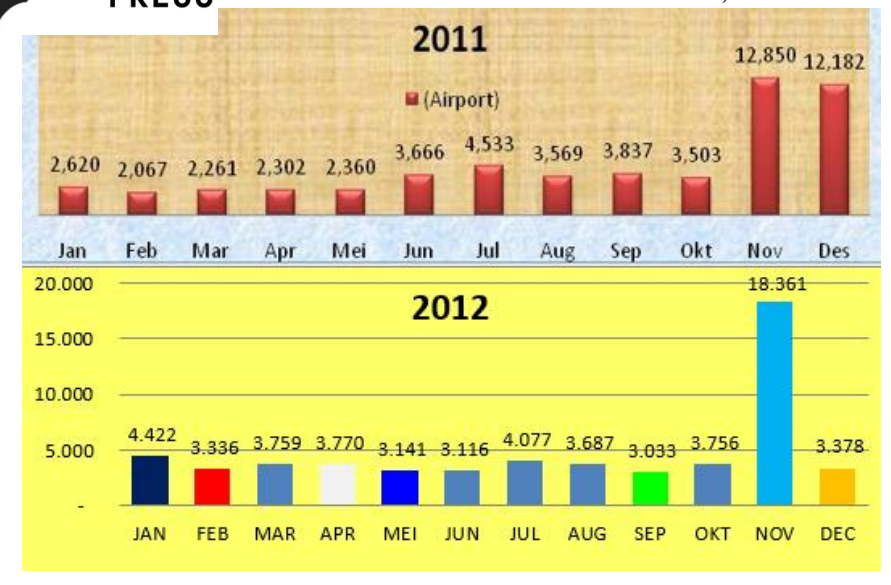

Figure 2. The Trend of Foreign Visitor Arrivals in Makassar through Sultan Hasanuddin Air-port in The Year 2011-2012.

Picture 2 showed that there were 2,620 foreign tourists who came or visited Makassar through Sultan Hasanuddin Airport in January 2011. Meanwhile, there were 4,422 foreign tourists in January 2012. It means there was 1,802 visitor difference between 2011 and 2012. It was due to the intensity and the interest in traveling in Makassar City was arouse, especially to foreign visitors from Asian Pacific.

The highest number in the second semester is in November 2011 where there were 12,850 foreign visitors. While, in November 2012 there were 18,361 visitors. It means there were 5,511 more foreign visi-tors in 2012. The rise was significantly increased. According to a trusted source of Angkasa Pura I Makassar, the Hajj pilgrimage took place in Novem-ber. Therefore, the rise was assumed as the pilgrims' international flights in Sultan Hasanuddin Makassar Airport.

The number had also been confirmed to The Re-gional Office of Religious Ministry of South Sula-wesi. On the contrary to previous findings, there was a decrease in December 2012 compared to December 2011. In December 2011 , there were 12,182 visitors where there were only 3,378 visitors in December 2012. In another word, there was a decrease as many as 8,804 visitors. This phenomenon happened due to the lack of promotional events that previously con-ducted by The Office of Culture and Tourism of Makassar City.

The result of the data analysis above indicated that there was a rise from month to month in 2011 and 2012 even though it was not that significant, with 2,086 difference. According to the analysis, the insignificant rise was influenced by the global econ-omy condition that still affected the countries in America and Europe as the sources of foreign tour-ists to South Sulawesi. Besides, the reduced intensi-ty in promotional activities and attractive events by the government of Makassar City greatly impacted the visits. In 2011, the government of Makassar City intensely held promotional events both in the coun-try and abroad as well as organizing more than 100 events all along the year. The result positively influ-enced a number of domestic visitors in 2012 , but not the foreign visitors. To achieve similar success for the next years, promotional activities and events that took place in 2011 should be performed more often in the future.

The number of foreign visitors who came to Ma-kassar in 2011 was 55,750 people meanwhile in 2012 was 57,836 or 2,086 difference higher in 2012. The data implied that the highest transportation mode for foreign visitors who came to Makassar was by using air transportations. The secondary data came from the passenger data who used various kinds of air flights in Sultan Hasanuddin International Airport Makassar (the data source taken from Angkasa Pura I Makassar, rearranged by the researchers, 2013).

\section{CONCLUSION}

The positive depiction of tourist growth in Makassar City should be optimally handled to support the de-velopment of Makassar City as a world's city. The usefulness and the effectiveness can be achieved through the use of available tourism attractions or the new creation of a potential object that should be developed, either natural, socio-cultural, or even hu-man-made creation so that they can increase the number of visitors to Makassar City. This concrete effort should be encouraged by increasing the man-agement quality and the frequency of attractive ac-tivities conducted so that more visitors come to Makassar City.

\section{REFERENCES}

[1] J. G. C. Kester, "2012 International Tourism Results and Prospects for 2013," United Nations World Tour. Organ. (UNWTO), Madrid, 2013.

[2] L. R. Allen, P. T. Long, R. R. Perdue, and S. Kieselbach, "The impact of tourism development on residents' perceptions of community life," J. Travel Res., vol. 27, no. 1, pp. 16-21, 1988

[3] C.-O. Oh, "The contribution of tourism development to economic growth in the Korean economy," Tour. Manag., vol. 26, no. 1, pp. 3944, 2005.

[4] J. Briedenhann and E. Wickens, "Tourism routes as a tool for the economic development of rural areas-vibrant hope or impossible dream?," Tour. Manag., vol. 25, no. 1, pp. 71-79, 2004.

[5] C. Jayawardena, C. Jayawardena, D. J. Patterson, C. Choi, and R. Brain, "Sustainable tourism development in Niagara: Discussions, theories, projects and insights," Int. J. Contemp. Hosp. Manag., vol. 20, no. 3, pp. 258-277, 2008.

[6] T. . R. Hinkin, J. . B. Tracey, and C. A. Enz, "Scale construction: Developing reliable and valid measurement instruments," J. Hosp. Tour. Res., vol. 21, no. 1, pp. 100-120, 1997.

[7] H. Wirawan and M. T. Bandu, "A review of self-efficacy training for international student," Int. J. Inf. Learn. Technol., vol. 33, no. 2, pp. $115-128,2016$ 